\title{
Challenges of delivering a graduate apprenticeship.
}

\author{
YOUNG, T., ZARB, M.
}

2019

(C) Owner/Author ACM 2019. This is the author's version of work. It is posted here for your personal use. Not for redistribution. The definitive Version of Record was published in Proceedings of the 24th Innovation and technology in computer science education annual conference, 15-17 July 2019, Aberdeen, UK, http://dx.doi.org/10.1145/3304221.3325566 


\section{Challenges of Delivering a Graduate Apprenticeship}

\author{
Tiffany Young \\ School of Computing Science and Digital Media \\ Robert Gordon University \\ Aberdeen, United Kingdom \\ t.young3@rgu.ac.uk
}

\begin{abstract}
Graduate Apprenticeship degree programmes look to overcome the segregation of learning and working, by integrating traditional education into the context of the work environment. This poster showcases a number of actions that were put into place to mitigate challenges that arose during the first run of these programmes.
\end{abstract}

\section{CCS CONCEPTS}

- Social and professional topics $\rightarrow$ Computing education.

\section{KEYWORDS}

Graduate Apprenticeship, Work-Based Learning, Support Student Success, Online Distance Learning

\section{INTRODUCTION}

Graduate Apprenticeships (GA) look to combine academic knowledge and qualification recognition along with practical skills development. Robert Gordon University (RGU) ran its first GA in 2017. This has now expanded to seven frameworks across RGU with the collaboration of seventy-seven industry partners. The primary drive behind the GA is to support employers to develop the skills of their workforce [2].

The School of Computing Science and Digital Media (CSDM) within RGU have adopted a blended approach to content delivery due to the large catchment area of employers and apprentices. This resulted in online distance learning as the primary delivery mode. Interactions were primarily through the Virtual Learning Environment with pre-recorded lectures and interactive video sessions using Blackboard Collaborate ULTRA being the main points of contact with students. Due to the structure of these degrees, students are expected to be work-based learners (WBL). The challenges of integrating work-based learning within higher education are well-documented [1], and these expected issues framed part of the curriculum development undertaken within the School of

\author{
Mark Zarb \\ School of Computing Science and Digital Media \\ Robert Gordon University \\ Aberdeen, United Kingdom \\ m.zarb@rgu.ac.uk
}

Table 1: Work-Based Learning Challenges and Mitigations

\begin{tabular}{ll} 
Expected Challenges & Mitigations \\
\hline $\begin{array}{l}\text { Students' access to } \\
\text { additional support }\end{array}$ & $\begin{array}{l}\text { On-Campus Days } \\
\text { Twilight Study Skills Appoint- } \\
\text { ments }\end{array}$ \\
\hline $\begin{array}{l}\text { Students' connection to } \\
\text { tutors and peers }\end{array}$ & $\begin{array}{l}\text { Use of Microsoft Teams } \\
\text { Interactive Weekly Sessions on } \\
\text { the VLE } \\
\text { Academic Visits to the Workplace }\end{array}$ \\
\hline Engagement with the & $\begin{array}{l}\text { On-Campus Days } \\
\text { Peer Review } \\
\text { taught content }\end{array}$ \\
$\begin{array}{l}\text { Variety of Assessment Styles } \\
\text { Interactive Weekly Sessions on } \\
\text { the VLE }\end{array}$ \\
$\begin{array}{l}\text { Students' prioritisation of } \\
\text { work commitments over } \\
\text { studying }\end{array}$ & Learning Plans \\
\hline
\end{tabular}

Computing Science and Digital Media at RGU. The mitigations outlined in Table 1 were put in place.

Learning plans are currently being used by students, mentors and academics to ensure that the module content better aligns with the professional content. This allows students to better integrate their studies within the WBL environment, with appropriate assessments that fit this context. On-campus days were introduced in the second year of the programme to supplement the online delivery style and encourage student engagement and access to additional support.

\section{FUTURE WORK}

The CSDM GA programmes are now in the middle of their second year, and it seems as if the initial challenges expected and encountered have been successfully mitigated against. There are now multiple avenues to allow staff and students to communicate, allowing a more collaborative approach to resolving any new challenges. With on-campus days being a new addition in 2018, RGU are discussing the potential benefits to the integration of more on-campus days in future years.

\section{REFERENCES}

[1] Belinda McLennan and Shay Keating. 2008. Work-integrated learning (WIL) in Australian universities: The challenges of mainstreaming WIL. In ALTC NAGCAS National Symposium. Citeseer, 2-14.

[2] Skills Development Scotland. 2019. Graduate Apprenticeships. https: //www.skillsdevelopmentscotland.co.uk/what-we-do/apprenticeships/ graduate-apprenticeships 